\title{
Analisis Resiko Kecurangan terhadap Sistem Pengelolaan Dana Kapitasi Jaminan Kesehatan Nasional Di FKTP Pemerintah Kota Bitung
}

\author{
ROCKY SOPUTAN ${ }^{1}$, JANTJE TINANGON ${ }^{2}$, LINDA LAMBEY ${ }^{3}$
}

\author{
${ }^{123}$ Program Magister Akuntansi, Fakultas Ekonomi dan Bisnis Universitas Sam Ratulangi \\ email: rockysoputan1979@gmail.com
}

\begin{abstract}
This study aims to analyze the risk of fraud against the National Healthcare Capitation Fund management system in Bitung City Government FKTP. The study is a qualitative research with case study approach. Data were obtained by conductngi in-depth interviews, observation, and documentation. The results showed that the risk of fraud management system capitation funds National Health Insurance Bitung City occurred. It is because of the weakness of JKN fund management system that is not compliant with regulations. It thus can disrupt health services. Additionally, the lack of internal control is due to the absence of supervision from the health department and Inspectorate offices, abnormality of the management of national health in surance capitation fund, and pressure from the work environment. The efforts to prevent fraud risk should be taken by establishing a structure of good control (supervision), especially the commitment of the he ad of health department followed by all employees included in FKTP level, applying Good Corporate Governance $(G C G)$ with transparency principle in JKN capitation fund management and performing internal audit function.
\end{abstract}

Keywords: fraud risk, system, JKN capitation funds

Abstrak. Penelitian ini bertujuan untuk menganalisis resiko kecurangan terhadap sistem pengelolaan dana Kapitasi Jaminan Kesehatan Nasional di FKTP Pemerintah Kota Bitung. Pen elitian ini adalah penelitian kualitatif dengan pendekatan studi kasus. Data diperoleh melalui teknik wawancara mendalam, observasi dan studi dokumentasi. Hasil penelitian menunjukkan bahwa resiko kecuran gan sistem pengelolaan dana kapitasi Jaminan Kesehatan Nasional di FKTP Pemerintah Kota Bitung terjadi karena lemahnya sistem pengelolaan dana kapitasi JKN yang tidak sesuai regulasi sehingga dapat menganggu pelayanan kesehatan, lemahnya pengendalian intern disebabkan tidak ada pengawasan dari Dinas Kesehatan dan Inspektorat, tidak normalnya pengelolaan dana ka pitasi JKN, dan tekanan dari lingkungan kerja. Upaya menanggulangi resiko kecurangan harus dimulai dari membangun struktur pengendalian yang baik terutama komitmen Kepala Dinas diik uti oleh seluruh pegawai sampai ke tingkat FKTP, menerapkan Good Coorporate Governance (GCG) dengan prinsip transparansi dalam pengelolaan dana kapitasi JKN, dan menjalankan fungsi Internal Audit

Kata Kunci: Resiko kecurangan, sistem, dana kapitasi JKN

\section{Pendahuluan}

Pelayanan kesehatan merupakan salah satu prioritas pemerintah, maka pemenuhan an ggaran kesehatan sebagai salah satu dimensi dasar pada pembangunan manusia dalam Anggaran Pendapatan dan Belanja Negara (APBN). Anggaran kesehatan ini digunakan untuk pemenuhan peningkatan cakupan pelayanan kesehatan universal dan kualitas pelayanan serta keberlanjutan pengelolaan sistem jaminan sosial nasional (SJSN). Sistem Jaminan Sosial Nasional atau Jaminan Kese hatan Nasional (JKN) merupakan program pemerintah yang dicanangkan sejak tahun 2014.

Sejak diberlakukannya Jaminan Kesehatan Nasional pada tahun 2014, resiko kecurangan (fraud) dalam layanan kesehatan semakin nampak di Indonesia. Resiko ini muncul dan dapat menjadi semakin meluas karena adanya tekanan dari sistem pembiayaan yang baru berlaku di Indonesia, adanya kesempatan karena minim pengawasan, serta ada pembenaran saat mela kukan tin dakan ini. Kecurangan dalam layanan kesehatan beresiko merugikan dana kesehatan negara dan menurunk an mutu layanan kesehatan. Dalam banyak kasus, resiko kecurangan dalam layanan kesehatan terjadi karena tenaga medis bergaji rendah, adanya ketidakseimbangan antara sistem layanan keseh atan dan beban layanan kesehatan, penyedia layanan tidak memberi insentif yang memadai, kekurangan 
pasokan peralatan medis, inefisiensi dalam sistem, kurangnya transparansi dalam fasilitasi kesehatan dan faktor budaya (Shahriari, 2001).

Di seluruh Indonesia, data yang dilansir KPK menunjukkan bahwa hingga Juni 2015 terdeteksi potensi Fraud dari 175.774 klaim Fasilitas Kesehatan Rujukan Tingk at Lanjut (FKRTL) dengan nilai Rp. 440 M. Ini baru dari kelompok klinisi, belum dari aktor lain seperti staf BPJS Kesehatan, pasien, dan suplier alat kesehatan dan obat. Nilai ini mungkin saja belum total mengingat sistem pengawasan dan deteksi yang digunakan masih sangat sederhana (KPK, 2015). Besarnya resiko kerugian yang ditimbulkan, mendorong pemerintah menerbitkan Permenkes No. 36 tahun 2015 tentang Pencegahan Kecurangan (Fraud) dalam Program Jaminan Kesehatan Nasional (JKN) pada Sistem Jaminan Sosial Nasional (SJSN) sebagai dasar hukum pengembangan sistem anti fraud layanan kesehatan di Indonesia. Sejak diluncurkan April 2015 lalu, peraturan ini belum optimal dijalankan. Dampaknya, resiko kecurangan ( fraud) dalam layanan kesehatan berpotensi semakin bany ak terjadi namun tidak diimbangi dengan sistem pengendalian yang baik. Komisi Pemberantasan Korupsi (KPK) turut juga memberikan perhatian terhadap pengelolaan dana kapitasi ini. Hasil analisa Komisi Pemberantasan Korupsi terdapat empat hal pokok dalam kelemahan pengelolaan dana kapitasi ini salah satunya adalah masalah sumber daya manusia.

Menurut Priharsa Nugraha humas Komisi Pemberantasan Korupsi (KPK) dalam rilisn ya di media Hukum Online 19 Januari 2015, hasil evaluasi lembaganya menemukan sejumlah persoalan:

Pertama, terkait regulasi yang mengatur pembagian jasa medis dan biaya operasional y akni Perpres No. 32 Tahun 2014 dan Permenkes No. 19 Tahun 2014. Regulasi itu berpotensi menimbulkan moral hazard dan ketidakwajaran karena kedua aturan ini menyebut dana kapitasi yang bisa digunakan untuk jasa pelayanan kesehatan sekurang-kurangnya enam puluh persen dari total penerimaan. Regulasi itu belum mengatur mekanisme pengelolaan sisa lebih dana kapitasi. Mekanisme kapitasi membuat dana yang masuk ke Puskesmas meningkat drastis melebihi kebutuhan Puskesmas setiap tahun. Jika terus terjadi, sisa lebih itu akan terakumulasi tiap tahun dan jumlahnya bisa sangat besar. Penggunaan dana kapitasi juga kurang mengakomodasi kebutuhan Puskesmas. KPK menilai peruntukan dan a k apitasi sebenarnya telah mampu dibiayai dari APBN/APBD sebagai belanja rutin. Kesulitan yang kerap ditemui lebih pada belanja non rutin seperti pengadaan dan rehabilitasi gedung. Kedua, aspek pembiayaan. KPK menemukan potensi fraud (penyimpangan) atas dibolehkannya perpindahan peserta penerima bantuan iuran (PBI) dari Puskesmas ke FKTP swasta seperti klinik. Fakta di lapangan menunjukkan oknum petugas Puskesmas mendirikan FKTP swasta. Kemudian, pasien yang datang ke Puskesmas tempat oknum itu bekerja tidak dilayani secara baik dengan berbagai alasan. Pasien y ang bersangkutan malah diarahkan ke FKTP swasta milik oknum petugas Puskesmas itu atau yang berafiliasi dengannya. Ketiga, tata laksana dan sumber daya. KPK menemukan sejumlah persoalan diantaranya lemahnya pemahaman dan kompetensi petugas kesehatan di Puskesmas dalam menjalankan regulasi. Proses eligibilitas kepesertaan di FKTP belum berjalan baik, begitu pula dengan pelaksanaan rujukan berjenjang. "Potensi petugas FKTP menjadi pelaku penyimpangan (fraud) semakin besar. Petugas Puskesmas rentan jadi korban pemerasan berbagai pihak serta sebaran tenaga kesehatan tidak merata," kata Humas KPK, Priharsa Nugraha, dalam keterangan pers y an g diterima hukum online. Keempat, KPK menyoroti soal pengawasan. KPK mencatat tid ak ad an ya anggaran pengawasan dana kapitasi di daerah. Itu diperburuk dengan absennya pengawasan dan pengendalian dana kapitasi oleh BPJS Kesehatan.

Dana kapitasi Jaminan Kesehatan Nasional (JKN) adalah dana yang dibayarkan secara berkala oleh BPJS Kesehatan kepada Puskesmas yang merupakan penyelenggara pelay anan ke sehatan atau sebagai salah satu fasilitas bagi peserta JKN. Sumber d ana kapitasi berasal dari hasil pengelolaan d an pengembangan dana iuran peserta JKN.

Pemerintah Kota Bitung telah mendapatkan predikat opini WTP pada hasil pemeriksaan Laporan Keuangan Pemerintah Daerah Tahun 2016 oleh BPK-RI. Dalam Laporan Hasil Pemeriksaan BPK-RI Sulawesi Utara atas Laporan Keuangan Pemerintah Daerah Kota Bitung Tahun 2016 Nomor 03.B/LHP/XIX.MND/05/2017 tanggal 29 Mei 2017, ditemukan catatan yaitu Pengendalian atas Pengelolaan Dana Kapitasi JKN Pemerintah Kota Bitung Kurang Optimal.

Dana kapitasi ditransfer oleh BPJS ke rekening FKTP/Puskesmas setiap tanggal 15 bulan berjalan, sesuai dengan jumlah kepesertaan JKN yang ada di wilayah masing-masing FKTP. Dana kapitasi yang masuk ke rekening FKTP selanjutnya disetor ke Kas Daerah oleh Bendahara JKN FKTP. Bukti tanda setor dalam bentuk Surat Tanda Setoran (STS), selanjutnya oleh Puskesmas diserahkan ke Bendahara Penerimaan PAD Dinas Kesehatan. Kemudian, Puskesmas melakukan penagihan Dana Kapitasi JKN, berupa belanja jasa pelayanan, belanja modal, obat dan barang habis 
pakai dalam bentuk pengajuan surat pertanggungjawaban ke Dinas Kesehatan sesuai dengan anggaran belanja yang tertata dalam Dokumen Pelaksanaan Anggaran (DPA). Belanja jasa pelayanan 70\% ditagihkan setiap dua bulan sekali oleh FKTP ke Dinas Kesehatan. Sedangkan untuk belanja modal, obat dan barang habis pakai sebesar 30\%, FKTP berkoordinasi dengan panitia pengadaan Dinas Kesehatan. Surat pertanggungjawaban diproses oleh Sub Bagian Keuangan Dinas Kes ehat an untuk dibuatkan Surat Perintah Membayar (SPM) yang selanjutnya ditagihkan ke Bendahara Umum Daerah (BUD) untuk diterbitkan Surat Perintah Pencairan Dana (SP2D). Setelah diterbitkan SP2D, dana Kapitasi JKN ditransfer ke rekening Bendahara Pengeluaran Din as Kesehatan, kemudian Bendahara Pengeluaran membagikan secara tunai ke Bendahara JKN di masing-masing FKTP dengan cara ditransfer. Sedangkan dana hasil tagih belanja modal, obat dan bahan habis pakai ditransfer ke rekening pihak ketiga dari kas Daerah.

Pemeriksaan atas pengelolaan dana kapitasi pada Tahun 2016 menunjukkan bahwa perta ma, terdapat keterlambatan pembayaran jasa pelayanan kesehatan dana kapitasi Tahun 2015 yang baru dibayarkan pada Desember Tahun 2016. Kedua, jasa pelayanan Puskes mas bulan Okt ober sampai dengan Desember 2016, masih belum dibayar sampai dengan 31 Desember 2016. Ketiga, penye rapan belanja operasional dana kapitasi JKN untuk FKTP belum seratus persen sesuai den gan ketentu an sehingga masih terdapat sisa dana yang belum dimanfaatkan.

Dana Kapitasi JKN pada Puskesmas dimanfaatkan untuk pembayaran jasa pelayanan kesehatan sebesar $70 \%$ dan untuk pembayaran dukungan biaya operasional pelayanan kesehatan berupa obat, alat kesehatan dan bahan habis pakai sebesar $15 \%$ serta kegiatan operasional pelayanan kesehatan lainnya sebesar $15 \%$. Menurut keterangan dari pengelola dana kapitasi Din as Kesehatan tidak melakukan pengawasan dalam proses pengadaan/pemanfaatan atas belanja operasional dana kapitasi JKN di masing-masing FKTP. Dana kapitasi JKN tersebut dikelola oleh bagian penga daan Dinas Kesehatan berkoordinasi langsung dengan FKTP. Juga ada pemotongan jasa pelayanan kesehatan sebesar 5\% kepada pegawai di Puskesmas.

Pelaksanaan pengadaan obat, alat kesehatan, bahan habis pakai kesehatan dilaksanakan pada akhir tahun anggaran hal ini disebabkan tidak ada penyedia atau pihak ketiga yang berasal dari dalam kota. Sehingga dalam melaksanakan pengadaan obat, alat kesehatan, bahan pakai habis me nunjuk satu penyedia dari luar Kota Bitung menurut bagian pengadaan Dinas Kesehatan Kota Bitung.

Penelitian ini bertujuan untuk: 1). Menganalisis resiko-resiko kecurangan terhadap sistem pengelolaan Dana Kapitasi JKN di FKTP Kota Bitung; 2) Upaya menanggulangi resiko-resiko kecurangan terhadap sistem pengelolaan Dana Kapitasi JKN di FKTP Kota Bitung.

\section{Model Analisis}

Model analisis dalam penelitian ini dikonsepkan dengan menguraikan secara rinci setiap permasalahan yang ada dengan alur terstruktur, mengenai pengelolaan dana Kapitasi JKN yang sesu ai dengan peraturan pengelolaan keuangan daerah.

Kemudian melakukan analisis dengan pendekatan metode kualitatif atas setiap pola maupun hubungan yang terbentuk berdasarkan fenomena dilapangan yang diperbandingkan dengan teori-te ori yang ada untuk kemudian ditarik suatu kesimpulan yang menjawab setiap ru mu san masalah dalam penelitian ini.

\section{Metode Penelitian}

Penggunaan metode studi kasus dikarenakan tujuan penelitian ini yaitu untuk memahami apa resiko-resiko kecurangan terhadap sistem pengelolaan dana kapitasi Jaminan Kesehatan Nasional yang masih bermasalah dari sisi objek penelitian FKTP (Fasilitas Kesehatan Tingkat Pertama pemerin tah Kota Bitung). Endraswara (2013:78) menyatakan bahwa studi kasus dibagi menjadi dua golongan, yaitu studi kasus berupa penyimpangan dari kewajaran dan studi kasuske arah perkemb angan yang positif.

Lewat studi kasus atas sistem pengelolaan dana Kapitasi JKN di FKTP pemerintah Kota Bitung, maka potensi-potensi kecurangan dapat diketahui bersama. Disamping menemukan dan menguraikan kendala-kendala yang dihadapi, pendekatan studi kasus berusah a menemukan tin dak lanjut berupa perbaikan atau strategi yang perlu dilakukan untuk mengatasi kendala y ang dihadapi dalam sistem pengelolaan dana Kapitasi JKN.

Teknik pengumpulan data dalam penelitian ini adalah melalui wawancara mendalam (In-depth interview), pengamatan (observation) dan dokumentasi (documentation). Wawancara dilakukan pada Auditor BPKP Perwakilan Provinsi Sulawesi Utara, Bendahara FKTP, Kepala FKTP, Kasubag 
Keuangan Dinas Kesehatan, Pengelola jaminan kesehatan nasional, Pejabat Pembuat Komitmen (PPKom) dan Inspektorat Kota Bitung.

Teknik pengujian keabsahan data hasil penelitian, peneliti mengunakan triangulasi. Dan teknik analisis data mengunakan metode analisis data yaitu analisis isi (content analysis).

\section{Analisis dan Pembahasan}

Penelitian dilaksanakan di Dinas Kesehatan Kota Bitung selama \pm 2 (dua) bulan yakni antara bulan Oktober sampai bulan November 2017. Instrumen pendukung yang digunakan adalah: buku catatan (notebook), pedoman wawancara, alat perekam berupa audio (voice recorder) / video recorder (handycam) untuk merekam pelaksanaan wawancara dengan informan yang hasilnya di transcribe menjadi transkrip data, kamera untuk mendokumentasikan kegiatan penelitian di lapangan, dan laptop untuk menunjang penulisan hasil penelitian. Adapun hasil penelitian dan pembahasan diuraikan sebagai berikut:

\section{Resiko-resiko kecurangan pengelolaan dana kapitasi JKN}

Resiko-resiko kecurangan pengelolaan dana kapitasi JKN di Pemerintah Kota Bitung adalah sebagai berikut:

\section{Lemahnya sistem pengelolaan dana kapitasi JKN}

Pengelolaan dana kapitasi Jaminan Kesehatan Nasional berdasarkan Perpres 32 tahun 2014 dapat digunakan secara langsung dan digambarkan sebagai berikut:

Gambar 5.9 Alur Mekanisme Pengelolaan Dana Kapitasi JKN Pepres 32 Tahun 2014

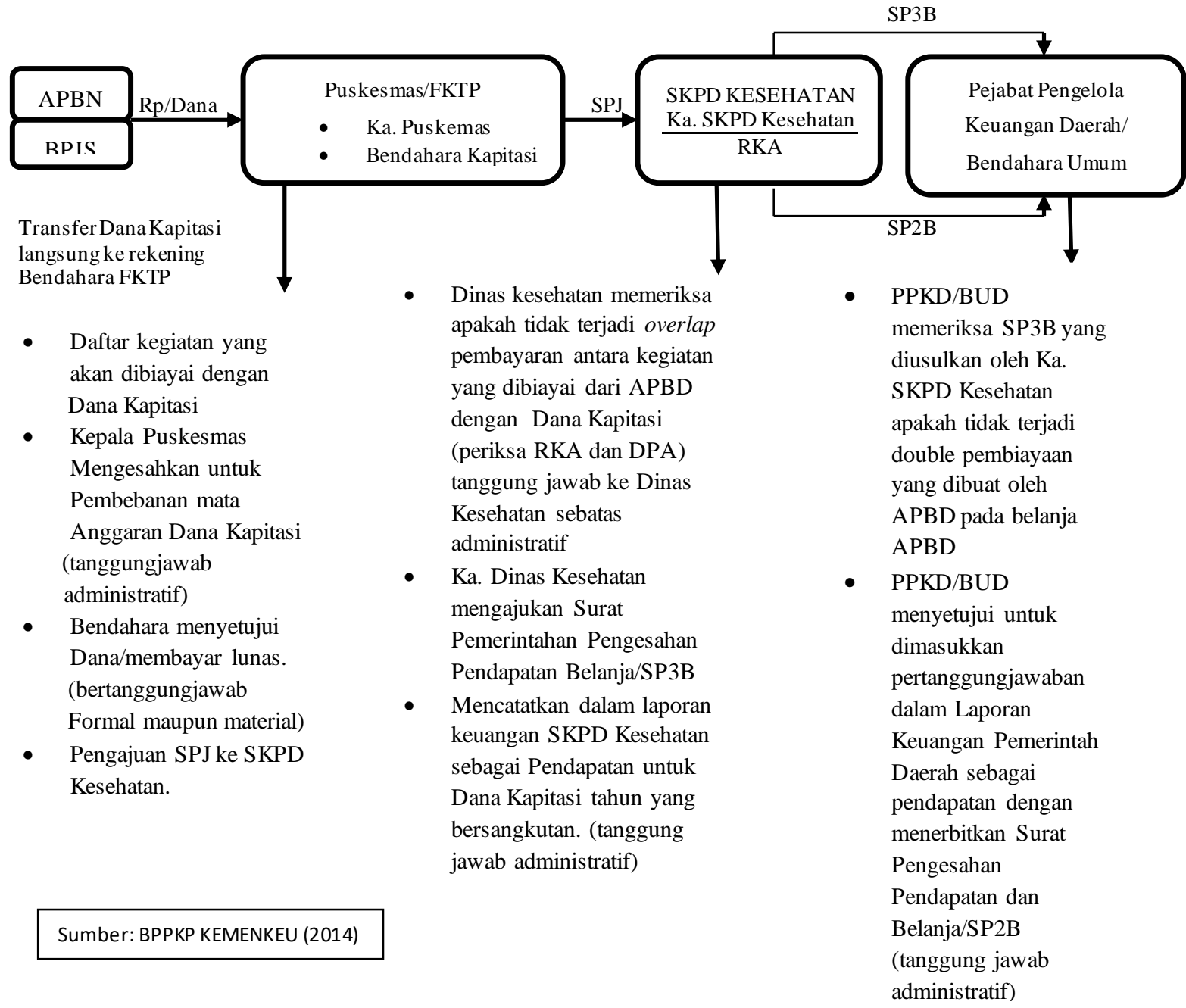


Pengelolaan dana kapitasi Jaminan Kesehatan Nasional di FKTP Kota Bitung dapat di lihat alur meknisme berikut:

Gambar 5.10. Alur Mekanisme Pengelolaan Dana Kapitasi JKN FKTP Kota Bitung

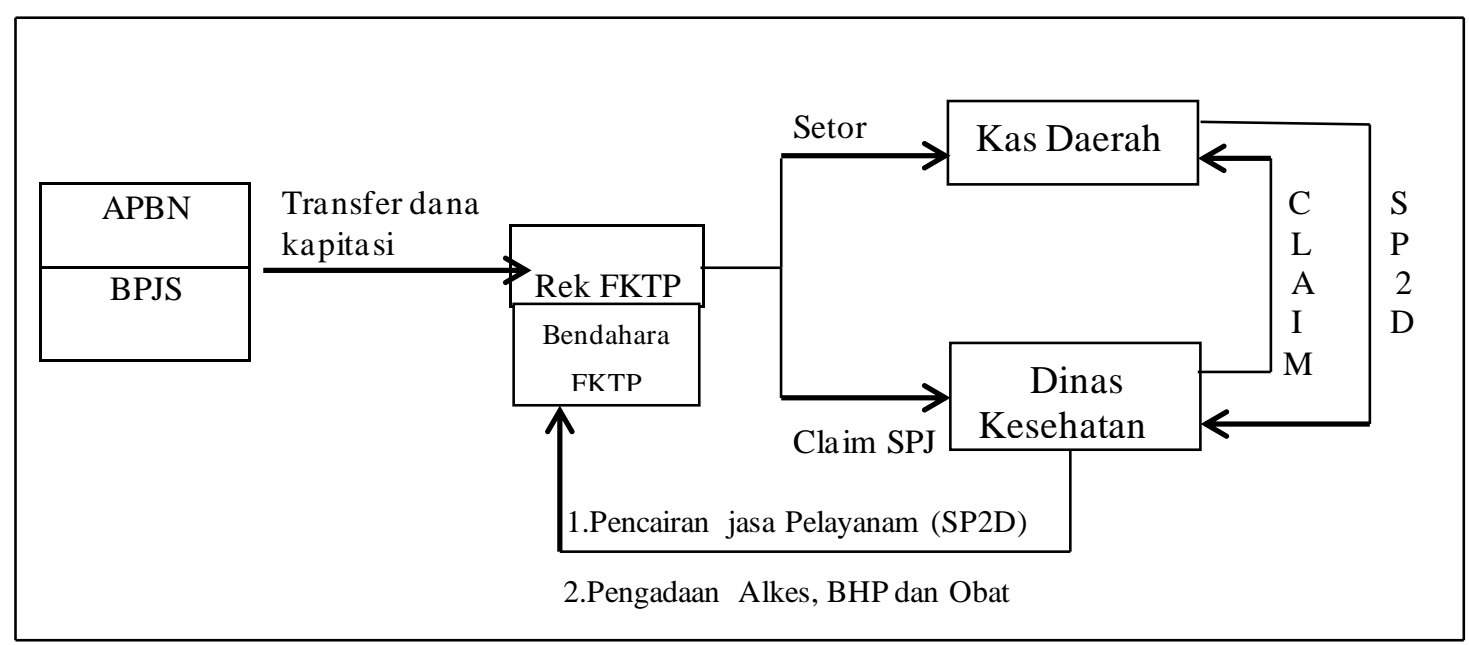

Sumber: Data Olahan (2017)

Sistem pengelolaan dana kapitasi JKN yang panjang dan berbelit-belit serta tidak sesuai dengan peraturan akan berdampak pada pencapaian tujuan dari Dinas Keseh atan Kota Bitung yang bergerak dalam pelayanan publik di bidang kesehatan. Sebagai organisasi publik yang menghasilkan jasa publik atau "public goods" kondisi yang dialami oleh FKTP di Kota Bitung mengalami kesulitan sebagai akibat dari regulasi pengelolaan keuangan dana kapitasi JKN yang belum dilaksanakan sesu ai peraturan dan terkesan sangat birokratis. Dalam banyak hal Shahriari (2001), resiko kecurangan dalam layanan kesehatan terjadi karena: (1) tenaga medis bergaji rendah, (2) adanya ketidakseimbangan antara sistem layanan kesehatan dan beban layanan kesehatan, (3) penyedia layanan tidak memberi insentif yang memadai, (4) kekurangan pasokan peralatan medis, (5) inefi siensi dalam sistem, (6) kurangnya transparansi dalam fasilitas kesehatan, dan (7) faktor budaya.

Dengan kata lain, stewardship theory memandang manajemen sebagai dapat di percaya untuk bertindak dengan sebaik-baiknya bagi kepentingan publik maupun stakeholder. Organisasi publik seperti Puskesmas dan Dinas Kesehatan yang berperan sebagai penyedia jasa barang publik bidang kesehatan dalam pengelolaan dana kapitasi Jaminan Kesehatan Nasional akan berusaha semaksimal mungkin untuk mengelola sumber daya publik ( principal) untuk kepentingan publik sehingga tujuan organisasi kesehatan dalam bidang promotif dan preventif dapat tercapai.

Tidak maksimalnya pelayanan di FKTP akan membawa masalah bagi FKPT dan Dinas Kesehatan. Sebagai organisasi publik proses pelayanan harus tetap dilaksan akan walaupun terjadi banyak pengeluhan dari masyarakat sambil mencari solusi dari permasalahan tersebut mendapatkan jalan keluar.

\section{Lemahnya pengendalian intern}

Kecurangan timbul karena lemahnya sistem pengendalian intern untuk mencegah dan mendeteksi resiko kecurangan itu sendiri, bisa juga dapat terjadi karena lemahnya sanksi, dan ketidakmampuan untuk menilai kualitas kerja (Tomi Setiaji, 2015).

“..Monev untuk dana kapitasi JKN kurang sekali karena dalam 1 tahun baru 2 kali diadakan pertemuan, itupun sudah jadi temuan baru Dinas bergerak. Dari Inspektorat tidak ada pemeriksaan khusus dana kapitasi JKN. (Informan 8 Commeted U52).

Lemahnya pengendalian internal ini juga dapat dilihat dalam pengadaan obat, $b$ arang habis pakai, alat kesehatan yang menunjang pelayanan di Puskesmas.

“..Untuk obat, alkes dan BHP dari dana kapitasi kita pakai sistem pengadaan dengan mekanisme penunjukan langsung, dari pembuatan HPS sampai penentuan pemenang. Karena 
paket pengadaan dalam jumlah kecil. Untuk harga sesuai dengan harga pasaran. Di Bitung kan tidak ada penyedia Alkes, Obat, dan BHP jadi torang pake penyedia dari luar Bitung yang punya track record bagus". (Informan 16 Commeted U90).

Pernyataan dari para informan lewat wawancara memberikan gambaran yang jelas bahwa lemahnya sistem pengendalian internal dari instansi terkait akan merugikan pelaksanaan program pemerintah dalam bidang pelayanan kesehatan. Apalagi maksud dan tujuan dari pemberian dana kapitasi ini. Menurut teori fraud triangle oleh Donald R. Cressey (1953) dalam To mi Setiaji (2015) bahwa kesempatan untuk melakukan kecurangan karena lemahnya pengendalian internal, lemahnya sanksi, dan ketidakmampuan untuk menilai kualitas kerja. Kondisi-kondisi tersebut jik a dimasukkan dalam pengelolaan dana kapitasi JKN dapat dilihat dalam pengadaan barang-barang kesehatan seperti obat, alat kesehatan dan barang habis pakai dimana adanya kerjasama dengan pihak penyedia. Hal ini dipengaruhi oleh gaya menajemen pemerintahan yang belum sepenuhnya menerapkan sistem pengendalian internal sesuai peraturan.

\section{Tidak normalnya pengelolaan dana kapitasi JKN}

Anomali atau ketidaknormalan data catatan akuntasi dalam pengelolaan dana kapitasi jaminan kesehatan nasional. Dapat dilihat dalam pernyataan berikut:

“...Kalau akhir tahun beban kerja so meningkat selain mo kerja perawat juga mo buat pertanggungjawaban keuangan. Sering salah dalam melakukan perencanaan anggaran sehinngga berpotensi masalah seperti jasa tidak dibayarkan dan dana kapitasi JKN lebih banyak di kas daerah “. (Informan 3 Commented U14).

“...Persoalan keterlambatan pencairan dana disebabkan kurang validnya data dari Dinas Kesehatan sehingga realisasi penerimaan lebih besar dari pendapatan dan belanja yang direncanakan. Juga rencana kegiatan yang sering terlambat karena menunggu usulan dari Puskesmas". (Informan 15 Commeted U89).

Dapat digambarkan bahwa resiko kecurangan dalam pengelolaan dana kapitasi JKN disebabkan ketidaknormalan data akuntansi dana kapitasi sehingga dana yang ada di kas daerah meningkat dari jumlah yang direncanakan. Hal ini tidak sesuai dengan proses pengelola an keu an gan daerah dalam Permendagri no. 13 Tahun 2006 mulai dari perencanaan dan penggangaran, pelaksanaan dan pertanggungjawaban, akuntansi dan pelaporan. Penilaian resiko pada sektor publik akan memberikan informasi kepada pimpinan untuk meminimalisir dampak dari resiko, serta sebagai dasar bagi instansi pemerintah dalam menyusun rencana strategis dan membantu menghindari pe mboros an APBN/APBD (Istiningrum, 2011). Menurut Priantara (2013) indikasi resiko kecurangan dapat dikenali dengan tanda-tanda sebagai berikut: 1. Anomali Akuntansi; 2. Kelemahan struktur pengendalian internal baik level transaksi maupun level entitas.

\section{Tekanan dari lingkungan pekerjaan}

Dalam Teori Fraud Triangle oleh Donald R. Cressey (1953) yang dimasukkan dalam penelitian Tomi Setiaji (2015) tentang resiko kecurangan pengelolaan dana kapitasi ad alah tekan an. Pada umumnya tekanan muncul karena kebutuhan atau masalah finansial, kebutuhan yang tidak terduga, tekanan dari lingkungan kerja seperti kurang dihargainya atas prestasi atau kinerja, gaji rendah dan tidak puas dengan pekerjaan.

“... Resiko kecurang yang lain tidak adanya rencana penggunaan yang tepat meskipun sudah ada dalam DPA, biasanya ketika uang ditarik dari rekening dana kapitasi oleh bendahara, uang tersebut tidak langsung digunakan sesuai DPA tapi dana tersebut dipakai untuk membiayai kegiatan dari APBD ataupun BOK”. (Informan 18 Commented U71).

Dari hasil wawancara terhadap informan kunci dapat disimpulkan bahwa tekanan berasal d ari lingkungan kerja dan kondisi keuangan tidak sehat dari dinas kesehatan dapat menimbulkan resiko kecurangan. Dalam penelitian Rezae (2003) mengemukakan bahwa resiko kecurangan pada laporan keuangan menjadi tiga kategori yaitu: 1) Struktur Organisasi, resiko kecurangan y ang berhubungan dengan struktur organisasi adalah struktur organisasi yang tidak memiliki pemisahan fungsi serta 
belum memadainya internal control yang ada; 2) Kondisi keuangan, resiko yang berhubungan dengan kondisi keuangan pada umumnya terkait dengan anomali pada laporan keuangan seperti pen entuan laba yang tidak realistis, tujuan yang tidak realistis dan atau kekurangan modal kerja, dimana hal itu memicu seseorang untuk melakukan fraud atas laporan keuangan; 3) Lingkungan bisnis dan indus tri, Resiko disebabkan karena perubahan di lingkungan organisasi yang tidak menguntungkan atau mengancam kelangsungan usaha. Menurut Fullerton dan Durtschi (2004) resiko kecurangan dapat ditempatkan dalam tiga kategori besar yaitu:

1. Resiko yang berhubungan dengan lingkungan perusahaan, yang meliputi gaya manajemen, sistem insentif, etika keseluruhan perusahaan, tekanan industri, dan hubungan suatu perusahaan dengan pihak luar.

2. Resiko yang berhubungan dengan pelaku, seperti setiap tekanan keuangan atau pekerjaan yang berhubungan, peluang untuk melakukan penipuan dan rasionalisasi.

3. Resiko yang berhubungan dengan catatan keuangan dan praktek akuntansi.

\section{Upaya-upaya menanggulangi resiko kecurangan pengelolaan dana kapitasi JKN}

Langkah-langkah untuk untuk menanggulangi resiko kecurangan antara lain:

\section{Membangun struktur pengendalian Intern yang baik}

Membangun struktur pengendalian intern yang baik berkaitan dengan lingkungan pengendalian yang merupakan tindakan kebijakan dan prosedur yang menga mb ark an keselu rahan sikap manajemen, direksi, dan pemilik dari suatu entitas atas pentingnya pengendalian intern (Arens, et.al dalam buku jasa Audit dan Assurance, 2008).

Untuk menanggulanggi resiko kecurangan pada pengelolan dana kapitasi JKN harus membangun suatu struktur pengendalian intern yang baik dimulai dari dalam organisasi yaitu komitmen dari Kepala Perangkat Daerah Dinas Kesehatan yang harus diikuti oleh seluruh pegaw ai sampai di tingkat Puskesmas.

Komitmen organisasi dalam pengelolaan dana kapitasi JKN harus dijalank an dengan baik dengan menanamkan rasa iklim kejujuran, keterbukaan, dan saling membantu yang akan membawa dampak yang baik dalam pelayanan kesehatan.

\section{Menerapkan Good Corporate Governance}

Menerapkan Good Corporate Governance merupakan salah satu cara dalam menanggulangi kecurangan yang harus dilaksanakan dalam pengelolaan dana kapitasi JKN. Setiawan (2014) memberikan pengertian good corporate governance sebagai berikut: "Bentuk hubungan antara manajemen suatu perusahaan, board of directors, pemegang saham, dan stakeholder lainnya. Hubungan ini meliputi berbagai aturan dengan terbentuknya struktur dan tujuan perusah aan yang pasti, dan cara mencapai tujuan serta pengawasan kerja perusahaan.

Penerapan Good Coorporate Governance yaitu transparansi dalam pengelolaan anggaran dana kapitasi JKN dengan membuat laporan keuangan dan pelaksanaan pengada an alat ke sehatan, obat, BHP. Transparansi pengelolaan keuangan daerah merupakan salah satu bentuk efektivitas dan efisiensi penyelenggaraan tata kelola pemerintahan yang baik

Keterbukaan informasi dalam pengelolaan dana kapitasi JKN merupakan cara meningkatkan dan mengoptimalkan layanan publik terhadap masyarakat melalui kebijakan/peraturan yang ef ektif, efisien mengingat masyarakat berhak memperoleh jaminan terhadap akses informasi publik/kebebasan. Oleh karena itu Dinas Kesehatan dan Puskesmas harus menerapkan prinsip-prin sip Good Corperate Governance.

\section{Menjalankan Fungsi Internal Audit}

Untuk mencegah terjadinya kecurangan dalam pengelolaan dana kapitasi JKN dibutuhkan peran Internal Audit seperti yang diungkapkan oleh Wardhini (2010), yaitu: semakin efektifnya peran internal audit, maka pencegahan kecurangan dapat dijalankan. Pencegah an kecurangan dapat dilakukan apabila internal audit sudah mampu mengidentifikasi kemungkinan terjadinya fraud. Sebaliknya, ketika internal audit tidak mampu mengidentifikasi kemungkinan terjadinya fraud, maka kecurangan akan terjadi dan membuat kerugian bagi perusahaan. Internal Audit Pemerintah Kota Bitung adalah Inspektorat.

Inspektorat sebagai lembaga internal berfungsi untuk melakukan pemeriksaan, penilaian, dan mengevaluasi kegiatan-kegiatan organisasi, serta memberikan masukan tentang upaya perbaikan. Hery 
(2013) mengemukakan bahwa audit internal adalah suatu fungsi penilaian yang dikembangkan secara bebas dalam organisasi untuk menguji dan mengevaluasi kegiatan-kegiatan sebagai wujud pelay anan publik organisasi perusahaan.

\section{Penutup}

Kesimpulan Penelitian tentang resiko-resiko kecurangan terhadap sistem pengelola an dana kapitasi JKN berikut:

1. Lemahnya sistem pengelolaan dana kapitasi jaminan kesehatan nasional akan membawa pengaruh dalam bidang pelayanan kesehatan. Karena sebagai organisasi publik di bidang kesehatan bila sistem tidak baik akan mengganggu kebutuhan medis..

2. Lemahnya sistem pengendalian intern dalam pengelolaan dana kapitasi JKN di FKTP Kota Bitung disebabkan oleh kurangnya pengawasan dari Dinas Kesehatan dan Inspektorat. Sebagai contoh proses pengadaan barang dan jasa kesehatan yang selalu dilaksanakan akhir tahun anggaran dengan satu penyedia.

3. Anomali/tidak normalnya pengelolaan dana kapitasi jaminan kesehatan nasional disebabkan adanya peran ganda sebagai perawat dan bendahara di puskesmas, perenc an aan anggaran y ang tidak matang, transaksi fiktif sehingga dana yang ada di kas daerah meningkat pada akhir tahun anggaran.

4. Tekanan dari lingkungan pekerjaan dapat menimbulkan resiko kecurangan dengan adanya pemotongan belanja jasa pelayanan kesehatan.

Upaya menanggulangi resiko-resiko kecurangan pengelolaan dana kapitasi JKN adalah sebagai berikut:

5. Membangun struktur pengendalian intern yang baik yang menggambarkan komitmen dari organisasi dari Kepala Dinas Kesehatan yang diikuti oleh seluruh pegawai sampai di tingkat Puskesmas dengan menanamkan rasa kejujuran, keterbukaan dan saling membantu y ang akan membawa dampak baik dalam pelayanan kesehatan.

6. Menerapkan Good Coorporate Governance dalam pengelolaan dana kapitasi JKN yaitu meningkatkan informasi tentang pengelolaan keuangan dana kapitasi JKN.

7. Menjalankan Fungsi Internal Audit dengan melakukan pemeriksaan dan mengevaluasi secara rutin.

Saran yang dapat diberikan dari penelitian ini bagi FKTP dan Dinas Kesehatan dalam pelaksanaan pengelolaan dana kapitasi JKN antara lain:

1. Pengelolaan dana kapitasi JKN sebaiknya mengikuti Perpres No 32 Tahun 2014 dan SE Mendagri 900/2280/SJ tanggal 5 Mei 2014. Dengan membuat standar operasional sendiri dengan berpatokan pada regulasi yang ada.

2. Perlu adanya pemeriksaan secara berkala baik dari Dinas Kesehatan maupun dari Inspektorat terhadap pengelolaan dana kapitasi JKN. Dan setiap FKTP harus membu at lap oran keu an gan perbulan sebagai keterbukaan informasi terhadap pengelolaan dana kapitasi JKN di Puskesmas.

3. Dinas Kesehatan supaya dalam pen yusunan anggaran dana kapitasi berdasarkan usulan masingmasing Puskesmas setelah dilaksanakan verifikasi dan melakukan pengendalian dalam pengelolaan dana kapitasi secara optimal.

4. Sebaiknya pembayaran jasa pelayanan dilakukan tanpa ada pemotongan dan berpatokan pada peraturan yang ada.

5. Adanya penandatangan fakta integritas dalam pengelolaan dana kapitasi JKN untuk menghindarkan dari perilaku kecurangan.

6. Penerapan Good Coorporate Gavermance harus dilaksanakan oleh seluruh pegawai di Dinas Kesehatan.

7. Dinas kesehatan harus melakukan monev dalam triwulanan dan inspektorat harus me masukan dalam program kerja untuk melakukan pemeriksaan dana kapitasi JKN

\section{Daftar Pustaka}

Andrianto, Nico. 2007. Transparansi dan Akuntabilitas Publik Melalui e-Government. Malang: Bayumedia. Publishing.

Alvin, A. Arens., Ellder, J. Ronald., Beasley, Mark S. 2008. Auditing dan Jasa Assurance Pendekatan Terintegrasi. Erlangga: Jakarta.

Abdul Sabaruddin, 2015. Manajemen Kolaborasi dalam Pelayanan Publik, Yogyakarta, Graha Ilmu. 
Anggit, Purwitasari, 2013. Pengaruh Pengendalian Internal dan Komitmen Organisasi dalam pencegahan fraud pengadaan barang. Skripsi. Universitas Widyatama.

Amrizal, 2004. Pencegahan dan Pendeteksian Kecurangan oleh Internal Auditor. Jakarta: Direk torat Investigasi BUMN dan BUMD Bidang Investigasi.

Association of Certified Fraud Examiners, 2008. Report to Nation on Occupational Fraud \& Abuse. Texas: The Association of Certified Fraud Examiners, Inc.

Balai Pendidikan dan Pelatihan Kementrian Keuangan, 2014. Dana Kapitasi BPJS: Pelaksanaan dan Pertanggungjawabannya. Makassar.

Bastian Indra. 2015. Akuntansi Kesehatan. Erlangga, Jakarta.

Badan Pengawasan Keuangan dan Pembangunan, 2009. Modul Diklat: Sistem Pengendalian Intern Pemerintah. Jakarta.

Endraswara, Suwardi. 2013. Metodologi Penelitian Sastra. Yogyakarta: CAPS (Center for Academic Publishing Service).

Fullerton, Rosemary R \& Cindy Durtschi. 2004. The Effect of Professional Skepticism on The Fraud Detection Skills of Internal Auditors. Working Paper Series. Utah State University.

Hery, 2013. Cetakan Kesatu. Potret Profesi Audit Internal. Bandung: Alf abeta.

Istiningrum, A.A. 2011. Implementasi Penilaian Risiko dalam menunjang pencapaian tujuan Instan si Pendidikan. Jurnal Pendidikan Akuntansi Indonesia, Vol.IX. No. 2, Hlm. 16-13.

Priantara, Diaz. 2013. Fraud Auditing \& Investigation. Jakarta: Mitra Wacana Media.

Rezaee. 2002. Fraudulent Financial Report.

Shahriari, 2001. Institutional Issues in Informal Health Payments in Poland, Washington DC.

Setiawan, Odi. 2014. Penerapan GCG (Tata Kelola Perusahaan yang Baik) dalam Pengadaan Barang dan Jasa Secara Elektronik (E-Procurement) di PLN Kota Balikpapan. E-Journal Ilmu Pemerintahan, 2(4): 3092-3104.

Soegiharto, M.V. 2012. Penerapan Operasional Risk Management untuk meningkatkan efisiensi dari Quality Cost pada PT.SLC. Jurnal ilmiah Mahasiswa Universitas Surabaya. Vol.1. No.1. 2012. ISSN: 2302-8203.

Setiaji, Tomi. 2015. Analisis Faktor Internal dan Eksternal sebagai bahan penyusun strategi pencegahan fraud dana Kapitasi Puskesmas di Kota Semarang. Jurnal Kesehatan Masyarakat. Vol. 3. No.3. ISSN: 2356-3346.

Soejono, Karni. 2000. Auditing Audit Khusus dan Audit Forensik dalam Praktik. Edisi Pertama. Jakarta FE UI (Bab 2 hal 24).

Smith W Robert and Mark Bertozzi 1998. "Principals and Agents: An explanatory model of public budgeting”. Joumal of Public Budgeting and Financial Management (Fall): 325 - 353.

Sutedi, Adrian. 2011. Good Corporate Governance. Jakarta: Sinar Grafika.

Tugiman, Hiro. 2006. Standar Profesional Audit Internal. Yogyakarta: Kanisius.

Tuanakotta, 2012. Akuntansi Forensik dan Audit Investigatif. Jakarta: Edisi 2, Salemba Empat.

Tunggal, 2011. Forensic \& Investigatif Accounting-Pendekatan Kasus. Jakarta: Harvarindo.

Wardhini, 2010. Peranan Audit Internal dalam Pencegahan Kecurangan. Skripsi. Sarjana Ek onomi, Universitas Widyatama.

Wilopo, 2006. "Analisis Faktor-faktor yang berpengaruh terhadap kecenderungan kecurangan Akuntansi: Studi pada Perusahaan Publik dan Badan Usaha Milik Negara di Indonesia". Simposium Nasional Akuntansi (SNA 9) Padang. Hal 346-366.

Wijaya, A. 2014. Implementasi Fraud Risk Management untuk Meminimalkan Risiko Kecurangan (Fraud) Pada Bagian Produksi dan Penjualan Perusahaan Makanan Wanda Putra Kencana Surabaya. Jurnal Ilmiah Mahasiswa Universitas Surabaya. Vol.3. No.2. ISSN: 2302-8203.

Widodo, Joko. 2011. Analisis kebijakan Publik (Konsep dan Aplikasi Proses Kebijakan Publik). Malang: Bayumedia.

\section{Peraturan-peraturan:}

Keuangan Daerah

-, Peraturan Presiden Nomor 32 Tahun 2014 tentang Pen gelola an dan Pemanfaatan

Dana Kapitasi Jaminan Kesehatan Nasional pada Fasilitas Kesehatan Tingkat Pertama Milik

Pemerintah Daerah. 
-, SE Mendagri No 900/2280/SJ tentang petunjuk teknis Penganggaran, Pelaksanaan, dan penatausahaan serta pertanggungjawaban dana kapitasi Jaminan Kesehatan Nasional pada Fasilitas Kesehatan Tingkat Pertama Milik Pemerintah Daerah.

-, Permenkes 36 tahun 2015 tentang Pencegahan kecurangan (Fraud) dalam Program Jaminan Nasional (JKN) pada Sistem Jaminan Sosial Nasional (SJSN).

-, Permenkes 19 tahun 2014 tentang Penggunaan Dana Kapitasi JKN untuk Jasa Pelayanan Kesehatan dan Dukungan Biaya Operasional pada FKTP Milik Pemerintah Daerah. Pemerintah.

, Peraturan Pemerintah Nomor 60 Tahun 2008. Sistem Pengendalian Intern

Permenkes 21 tahun 2016 tentang Penggunaan Dana Kapitasi JKN untuk Jasa Pelayanan Kesehatan dan Dukungan Biaya Operasional pada FKTP Milik Pemerintah Daerah. -, SK Walikota Bitung Nomor 188.45/HKM/SK/124/2014 tanggal 30 Mei 2014 tentang Penunjukkan Bendahara Dana Kapitasi Jaminan Kesehatan Nasion al pada FKTP di Bitung.

------------, SK Walikota Bitung Nomor 188.45/HKM/SK/26/2015 tanggal 19 J an uari 2015 tentang Penetapan Alokasi Dana Kapitasi Jaminan Kesehatan Nasional.

Media Internet

Media Hukum Online 19 Januari 2015 diakses pada tanggal 2 september 2015. 